\title{
Interrogating of cancer genomes: towards more profile-based therapeutics
}

\author{
John David Carpten \\ From Beyond the Genome 2012 \\ Boston, MA, USA. 27-29 September 2012
}

\begin{abstract}
Although death rates due to common diseases such as heart disease, stroke and infectious diseases have declined over the last half-century, there has been only a small change in cancer mortality rates. The availability of the draft human genome sequence and a number of technological advances now provide us with the opportunity to explore the genomic landscape of cancer in an unprecedented way. Here, we will describe the application of multiple genomic technologies toward the interrogation of a number of cancer genomes, in order to discover molecular determinants of cancer that might be associated with clinical outcome and those that might be candidates for targeted therapy. It is our hope that these data would one day be translated into clinical practice to improve therapeutic decision-making for more knowledge-based clinical management.
\end{abstract}

Published: 1 October 2012

doi:10.1186/1753-6561-6-S6-016

Cite this article as: Carpten: Interrogating of cancer genomes: towards more profile-based therapeutics. BMC Proceedings 2012 6(Suppl 6):016.

Submit your next manuscript to BioMed Central and take full advantage of:

- Convenient online submission

- Thorough peer review

- No space constraints or color figure charges

- Immediate publication on acceptance

- Inclusion in PubMed, CAS, Scopus and Google Scholar

- Research which is freely available for redistribution

\section{Biomed Central}

